\title{
THE IMPACT OF ENGLISH ON CUBAN SPANISH: A GLOSSARY-BASED ANALYSIS OF MORPHOLOGICAL ADAPTATIONS (PART 1)
}

Keywords: Cuban Spanish, anglicisms, contrastive glossary, lexico-semantic analysis

\begin{abstract}
This article is intended to explore the linguistic means of anglicization in Cuban Spanish. Thus, a corpus-driven database or glossary of this variant of Spanish has been elaborated to examine these English-induced units quantitatively and qualitatively, entailing a morpho-syntactic and semantic analysis of the anglicization process. This research study is based on two major stages: data collection and data processing of the lemmas compiled. The resulting glossary is used in this part of the study to unravel the morphological and syntactic features of the English-induced units, in particular those of gender and number. A compilation of these Cuban-Spanish units allows for a better understanding of morphological changes and lexical creativity, in keeping with the historical socioeconomic conditions of the island. The collection of colloquialisms, vulgarisms or obsolete words corroborates the diastratic and diaphasic evolution of lemmas, and unveils some distinctive word-building patterns.
\end{abstract}

\section{Introduction}

An initial bibliographical search has confirmed that not much work has been dedicated to the impact of English on Cuban Spanish (henceforth $\mathrm{Cu}$.), particularly in terms of lexical creativity and semantic variations. Most of the sources consulted (López Morales 1970, 1971; Lorenzo 1996; Cárdenas 1999; Fasla 2007-2008) are right in saying that there is a need to study the sociolinguistic implications and adaptations of the anglicizing process of this Spanish variety. 
Thus, this article is intended: (1) to show how a contrastive Cuban Spanish glossary ${ }^{1}$ of anglicisms has been developed, and (2) to perform a lexico-semantic analysis of English-induced units in more detail. The information provided by these lemmas reveals the following markers: lexical frequency, morpho-semantic variations and sociolinguistic traits.

This corpus-driven database allows for a comprehensive analysis of the process of anglicization: most frequent types of lexical borrowing, sociolinguistic connotations, spelling or semantic changes, metaphorical extension of meaning, most frequent semantic fields, differentiating lexico-semantic features, in contrast with European Spanish (henceforth $\mathrm{Sp}$.) regarding anglicization and calquing.

To have a better understanding of the linguistic impact that English could have had on Cuban Spanish, the following sections have been conveniently arranged to show some of these aspects in more detail. Part 1 is intended to provide a brief historical revision of the presence of English in Cuba, a state-of-the-art description of the typology of anglicisms, and a morpho-syntactic analysis of these Englishinduced units. Part 2, on the other hand, explores the processes of direct and indirect borrowings in a Cuban Spanish corpus, and reassesses the influence of English on the level of semantics.

\section{English and Cuban Spanish: A brief historical account}

Undoubtedly, the impact of English on Cuban Spanish has been historically associated with an array of factors: geographical proximity, unstable political and social unrests, and social prestige. The colonial period (eighteenth and nineteenth centuries) was characterized by limited English influence: earlier dictionaries and glossaries (DPFC 1875; Marinello 1926-1927) reveal that gallicisms outnumbered English-induced units by far. Nevertheless, some studies (Pérez 20o8; Sánchez 2016) suggest that dailies and magazines of the time, e.g. Diario de La Marina, Rosendo, Bohemia, Juventud, etc., have indications of a deep assimilation of these English forms. As regards baseball-related words, this period represented the starting point of an expanding adaptation process, whose cultural novelty in the language triggered an influx of wide-ranging and innovative word stock.

During the so-called 'Neocolonial' period (1902-1958), English became the second language in importance in the country, as a reflection of strong political and economic tights between the US and Cuba. Migration was not as relevant as subsequent periods: only $0.36 \%$ of islanders were of US origin (Cervantes-Rodríguez 2010: 135). Instead, the flourishing Cuban bourgeoisie was responsible for embracing

The full glossary has been recently published in the form of a brief dictionary (DELCS 2017). This paper looks into both the methodological procedures followed and the morpho-syntactic and semantic structures of the English-induced lemmas, rather than the presentation of the glossary. However, a number of examples have been introduced throughout the text, approximately 400, to help readers visualize the dimensions of the anglicization process in Cuba and the typology of the data. 
the Americanized social standards: "the Cuban language would undergo the impact of this dissemination: beauty parlors, canasta parties, baby showers, country clubs, business academies, etc." (López Segrera 1989: 185).

After Fidel Castro's Revolution in 1959, new political and social shifts were inevitably reflected in the process of Anglicization:

\begin{abstract}
Nadie puede negar que con el triunfo de la Revolución Cubana, disminuyera grandemente el uso del idioma inglés oficialmente al sustituir toda una serie de anglicismos por términos equivalentes en nuestro idioma. Sin embargo, tampoco se puede negar que, a pesar de los cambios producidos en nuestra sociedad, la influencia de la lengua inglesa sea fuerte, pues existen otros fenómenos o motivaciones que coincidan su uso. Así lo demuestra e impone el propio contacto y desarrollo de determinadas esferas y tecnologías en la actualidad, y en consecuencia, la incorporación y empleo de palabras como: stress, test, líder, pitcher, show, bar, barman, block, champú, hit, marketing, ticket, bisté, cake, file, printer, mitin, spray, zipper, blúmer, coctel, bacon, frigidaire, etc. (Valdés 1998: 112)²
\end{abstract}

Despite the decline of word coinages after 1958, this type of borrowing continued, but at a different rate. The post-1958 period is particularly characterized by undergoing fresher assimilation processes, which are fully conditioned by the new socioeconomic situation in Cuba: a continuous inflow of already-coined anglicisms, especially those having to do with sports, pastimes, household appliances or furniture; a considerable increase in tourism-related vocabulary, tending to convey differentiating markers (bus, guagua 'bus'; cigar, tabaco 'Cuban cigar'); a rising assimilation of Cuban-American English-induced lexical units, and an expected redistribution of semantic load: these anglicisms (e.g. brother, bye-bye, part-time, drinking) are mostly either colloquial or informal in present-day Cuban Spanish.

Another interesting feature of the post-1958 period was that Cuban identity or nationality was no longer expressed in the national territory. The feeling of Cuban-ness transcended beyond the island's borders, especially to South Florida. Cuban-Americans became carriers of culture and identity at a social scale outside Cuba (cf. Sánchez 2017). Considering that by 2010 there were a total of 1,884,00o people of Cuban origin living in the US (PEW Research Center 2012), it is easy to understand that Cuban Spanish became largely in contact with American English, and that it became ingrained in Cuban migrants to keep in touch with their relatives on the island, which is perceptible in the number of yearly trips or family remittance. All this "indirect" diffusion of English has opened new sources of linguistic permeability, leading to a continuous assimilation of anglicisms in Cuba: day care, medicare 'statefunded healthcare', affidavit, part-time, estráples (< strapless), etc.

2 (Translation is mine) It is undeniable that with the triumph of the Cuban Revolution, the official use of English decreased drastically as many of these English terms were replaced by equivalent ones in our language. However, we cannot deny either that, in spite of the changes introduced in our society, the influence of English is still strong, particularly due to other phenomema and motivations that justify their usage. This is visible through the current language contact and development of specific domains and technologies, and consequently, the importation and usage of words such as stress, test, líder, pitcher, show, bar, barman, block, champú, hit, marketing, ticket, bisté, cake, file, printer, mitin, spray, zipper, blúmer, coctel, bacon, frigidaire, etc. 
The fresher sociocultural values of Cuban-American Spanish are linked to the existence of bi-culturality in southern Florida, which entails a unique prevalence of monolingual Spanish speakers. Spanish, as suggested by Otheguy and García (1988: 207), "enjoys more prestige and is associated with a more powerful and influential minority, and one that represents a much larger proportion of the total population, than is the case with Spanish in most other Hispanic communities of the US”.

\section{Lexical borrowing: Typology and concepts}

The present analysis, centred on the influence of English on Cuban Spanish, has drawn on this initiative of parallel corpus-based studies to establish a national database of loanwords and calques (GLAD), ${ }^{3}$ accompanied by a quantitative and qualitative examination of loanwords.

A preliminary collection of concepts and categories from prior studies is of great importance to review the operating theoretical foundation. It should certainly serve to understand the process of linguistic anglicization more profoundly, and to depict the notions linked to the assimilation of English-induced loans. However, not all the processes involved are of purely linguistic nature, which is why some remarks will be devoted to the pragmatic or sociolinguistic sources of borrowing.

Various taxonomies of anglicisms have been traditionally suggested (e.g. Lüdtke 1974; Otheguy, García 1988), and they all coincide in the morpho-semantic differentiation of borrowings. To have a better understanding of the classification grounds, a typological chart (see Figure 1), containing categories of lexical borrowings, has been introduced to offer a state-of-the-art and unifying overview of the most relevant concepts regarding lexical borrowings and calques (Furiassi et al. 2012: 6). Typologically, calques and borrowings are occasionally studied as different processes, but they can be equally motivated by graphemic or semantic transference. This feature is key to coin a global terminology encompassing other subcategories, which share similarities in the way linguistic assimilation and transference occur between two languages in contact.

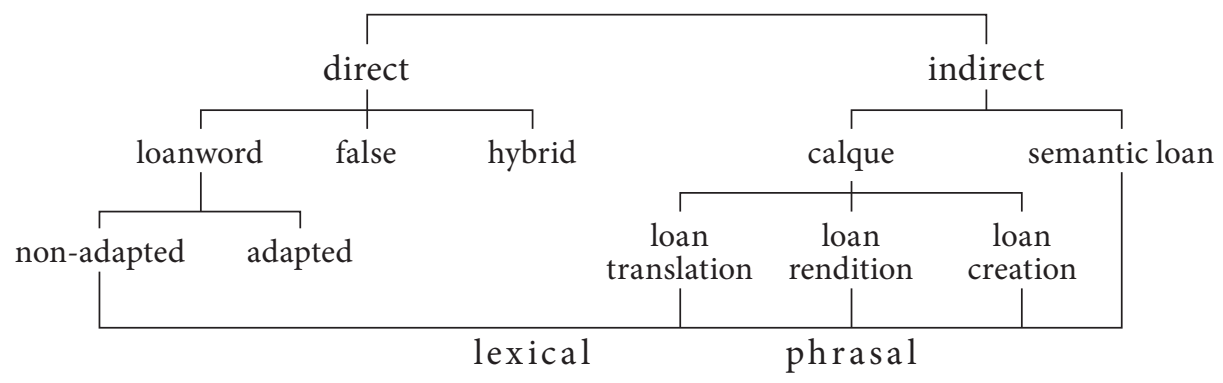

Figure 1. Types of lexical borrowings

GLAD (Global Anglicism Database) Network is aimed at studying the influence of a common source language (English) on a number of recipient languages, including the Cuban variant of Spanish. 
The first distinction is made between direct and indirect borrowings (for a detailed examination of this typology in Cuban Spanish, see Part 2). "Direct borrowings" from a source language (SL) to a recipient language (RL), or target language, tend to show evident elements of the SL, i.e. English. These elements are not obviously detected or conveyed in the same manner (loanwords, false loans, hybrid loans). "Indirect borrowings" (calques and semantic loans) are not as easy to spot as direct ones: SL models are reproduced by translation in the RL (calques) or by alreadyexisting elements in RL, which acquire new meanings (semantic loan).

In the case of loanwords, and based on the degree of integration of the units in the RL, anglicisms are divided into two types: non-adapted and adapted. A non-adapted loanword is a word or multi-word unit "without or with minor formal and semantic integration, so that it remains recognizably English in the RL" (Furiassi et al. 2012: 6). By and large, phonological integration takes place due to evident differences between the phonological systems of RL and SL (bull-pen, all right, average). An adapted borrowing is a word or multi-word unit borrowed with orthographic, phonological and/or morphological integration into the systemic structures of the RL. Semantically, RL and SL's meanings are related (béisbol < baseball, bacha 'a get-together' < batch, cloche < clutch, chingala < shin-guard). Hybrids, also known as loanblends or semi-calques, refer to partial translations in which bases of both languages in contact are used in the same anglicism: línea de foul $<$ foul line.

False or pseudo-loans are not exclusively examples of the arbitrary nature of the linguistic sign. They are SL-induced units, whose meanings differ markedly from their English forms but they are clearly influenced by the English semantic structure: frozen 'watery ice-cream' (Cu.) does not fully convey the meaning of an ice-cream in English, but there exists an undeniable transference of semantic traits from the SL into the RL (Cuban Spanish); dancing is probably either a shortened element from the multi-word unit: $a$ dancing club, or a rarely-seen corruption of English grammar, in which an -ing form denotes place. At times, pseudo-loans are perceived as extensions of meaning in the RL, resulting in the formation of new senses, inexistent in English. Semantic pseudo-anglicisms are, in general, the construct of naturally unfolded meanings in the recipient language, whose "Englishness" is merely perceived through spelling and/or pronunciation.

As regards "calques", there are three global forms: loan translation, loan rendition and loan creation. A "loan translation" is a calque par excellence; it is a word or a multi-word unit which translates a SL unit into a RL one, i.e. from English into Spanish (arco del pie < arch of the foot, bombero 'a type of baseball player' < fireman, chivo < goatee). A "loan rendition" is a one-word unit or multi-word unit which translates an English element only partially and an inexact equivalent in the RL is given: árbol del pan < breadfruit tree. Finally, a "loan creation" is a new word or multi-word unit in the RL which freely renders the English pattern word in Spanish. It is, in short, "defined as a free loan translation that bears no formal and structural resemblance to the foreign model" (Gómez 1997: 93): jardinero 'a baseball player in the fields' < fielder, lanzarse de barriga < to slide onto base. These forms are chiefly motivated by the referents they signify. 
A "semantic loan" mostly depends on the type of motivation induced by other linguistic levels. All semantic loans or loan shifts share the semantic extension (homonymy or polysemy) of already-existing units in the RL. This semantic shift is accompanied by two possible morphological variations of the elements: (1) the adoption of RL morphological structures, whose motivation is purely semantic (amarillo 'coward' < yellow, apretazón 'medical condition' < tightness); (2) the morphological and phonological accommodation of paronymic units, similar to their SL counterparts, whose coincidental graphemes remind us of indigenous units (cana 'prison' $<$ can, aplicador < applicator). The latter elements undergo an induced process of assimilation by camouflaging into the RL through already-existing units. Thus, through a necessary process of homonymy, these lexical units provide new semantic features to native words. This uncommon assimilation process varies widely in accordance with the degree of morphological accommodation: from "highlycamouflaged" (cana < can) to clearly-detectable ones (aplicador < applicator).

The above-mentioned distinction is what Haugen (1950: 219-220) and Humbley (1974: 58-61) refer to as "homologues" and "analogues". The former denotes the units showing analogy of meaning, whose form, though a proper translation, is quite different. They share a primary literal meaning, in which the SL unit transfers a new meaning to its RL homologue. On the contrary, the latter refers to the units showing analogy in form as well as in meaning (generally linked to etymologically related words or "cognates").

\section{Methodology}

This research of Cuban-Spanish anglicisms, as commented earlier, consists of two general stages: (1) data collection, or extraction of contextualized lexical units, and (2) analysis of the information (lemmas) extracted and formatted. The former phase is characterized by the compilation of lexical units and their corresponding contextualization (if available). This revision process is based on the following three main sources: (i) Cuban Spanish (and European Spanish) glossaries and dictionaries; (ii) dailies and periodicals, e.g. blogs, books, magazines; and (iii) linguistic contributions from the Cuban community living in Spain.

The revision of Spanish dictionaries and/or glossaries of both varieties allows for a "contrastive" study, in which words are contrasted with their European Spanish counterparts. A total of fourteen dictionaries have been revised: DPFC 1875; Marinello 1926-1927; NCC 1974; Santiesteban 1985; Cárdenas 1999; DMC 1999; DEC 2003; González Mafud 2010; CDCE 2012; CREA 2014; CORDE 2014; DLE 2014; and GDA 2017. As it was not possible to perform interviews and collect data in Cuba, a number of thirty-six Cuban interviewees, ${ }^{4}$ currently living in Spain, participated in the data-collection stage. Their contribution, though limited in number,

4 Initially, the interviews were conceived for a larger number of informants in Miam-Dade area, but the influence of Cuban-American Spanish was higher than expected. 
allowed for a more thorough checking of dictionary-based sociolinguistic markers, e.g. 'obsolete', 'formal', 'slang', 'colloquial', etc. The selection of the informants was based on two criteria: (i) less than one-year residence in Spain (to avoid log-term influence from European Spanish), and (ii) variability of education level (fourteen interviewees are university graduates; sixteen finished pre-university level; and six possess a secondary school level). There was no questionnaire form, but merely a selection of words that were used in brief conversation stretches, which informants were supposed to classify according to the aforementioned markers, and lexical frequency. Determining which words needed further examination depended on dictionary incongruence or mismatch. Although the interviews were not used for the collection of new words, sometimes unregistered derivatives (beisbolero < baseball) or English-induced phrases (patear la lata < to kick the bucket) were also recorded. The interviews were carried out face to face or through video chats, and they lasted from June 2015 to September 2016.

These three types of sources have been really helpful in the annotation of lexical units, and their corresponding traits: co-text, etymology, synonym(s), phonetic transcription (if necessary), semantic field, etc. One distinguishing feature of the annotated lemmas, as appointed above, is that only those lemmas that are not used in European Spanish have been attested. This type of "contrastive" glossary could be of great importance to provide more specifications on the origins and nature of spelling, phonetic or semantic shifting, and also to conduct contrastive studies with other linguistic variants (cf. Montero 1995; Arnal 2009). Taking into consideration that a differential glossary of this kind is arguably "limited" (cf. Ávila 2003-2004), as it only includes autochthonous anglicisms that are only existent in Cuba, it is understandable that contrasting $\mathrm{Cu}$. with other Spanish variants of the American regions could be a lengthy and painstaking task, particularly in terms of etymology and borrowing. The elaboration of this type of glossary or database of anglicisms, in contrast with European Spanish, is based on both the availability of dictionaries of anglicisms in Spain, and the morpho-semantic variations driven by distinctive sociolinguistic settings and geographical features (cf. Rodríguez 1995). Therefore, as two Spanish varieties have been selected for the study, the use of the term "contrastive" (Haensch 1991: 51), rather than "differential", seems to be more accurate in the present research.

\section{Morpho-syntactic analysis of the data}

The number of autochthonous anglicisms totaled 818. This number includes the entries being differentiated due to possibly major spelling changes, ${ }^{5}$ which may

\footnotetext{
Although these words are merely spelling variations of the same entry, some of them have been purposefully treated as individual entries in the glossary to visualize: (1) the distinction of loanword typology, e.g. catcher (direct non-adapted) and cácher or quécher (direct adapted); (2) some sociolinguistic traits, e.g. baseball (obsolete); (3) homonymic clash due to spelling variation, e.g. fai $(<$ five $)$, fai $(<$ file $)$.
} 
well result in semantic shifting: baseball/béisbol, cácher/catcher, bunch/bonche, pie/ pay, files/fields. In the former doublet (baseball/béisbol), baseball is an obsolete word and it only remains in technical texts whereas the second entry is commonly found, together with its colloquial form pelota. In the case of files/fields, the distinction made of both entries relies on both spelling and idiomatic meaning: estar en los files 'to be at the very back of a place' < fields; fields is merely used to denote a baseball position.

On the whole, the glossary has 984 lexico-semantic variants (or senses), which are specified numerically in the entries. Few of these variants are shared with the European variant of Spanish, but they have not been removed to show how such senses might be distributed in a given entry.

A total of seventy-four idioms have been specified in the entries, and the majority of them are chiefly metaphorical extensions of the lemma in question: haber movimiento en el bullpen 'to have the feeling a situation is changing abruptly' < bullpen, comerse un cake /kéi/ 'to feel let down by something or another person' < cake, quitar el catao 'to stop thinking or worrying about something' < cut-out (box). The multiword phrases are motivated by situational context, and most of them are colloquialisms. Curiously, a number of expressions correspond to baseball-related idioms, conveying thus a significant degree of linguistic assimilation of baseball terms into colloquial $\mathrm{Cu}$.

A comprehensive analysis of the glossary shows that nouns or noun phrases account for $74.9 \%$ of the lemmas (see Figure 2). The other word classes in descending order of importance are: verbs and verb phrases (16.7\%), adjectives and adjectival phrases (6.8\%), adverbs and adverbial phrases (1.1\%), and interjections (nearly $0.5 \%$ ). The superiority trend of nouns, in contrast with other word classes, has been repeatedly observed in analogous studies (Cárdenas 1999; Rodríguez 2002). This responds to the fundamental need for denoting inexistent referents in the mother tongue, rather than actions. Lexical loans, chiefly the ones resulting from noun-forming processes, compensate the lack or absence of the word stock.
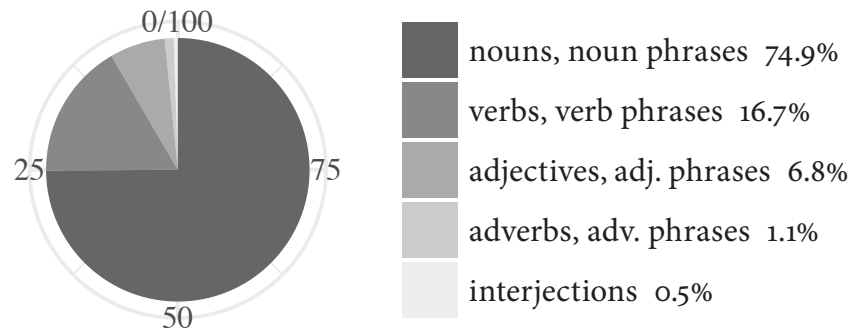

Figure 2. Word class of the lemmas compiled

The number of transitive and intransitive verbs, and verb phrases represent $25.8 \%$, $33 \%$ and $41.2 \%$, respectively, of all the verb forms extracted. These percentages imply that verb phrases account for nearly half of the total figure. Verb phrases, i.e. verbal idiomatic expressions, are lexical units mostly resulting from a semantic extension 
of literal senses (botar la pelota ${ }^{6}<$ to hit out the ball 'to do a task successfully'). It may well be the combination of an English word with a native phrase, spawning a common word-building process of lexical anglicization: vivir en week-end 'to idle'; medir el antifrizer 'to be homosexual' < antifreeze.

\subsection{Number and gender assignment}

Number markers in nouns are patternless. In the glossary, the anglicisms following standard plurality rules account for the majority of the units: baffles, barbecues, hits, bates < bat, bayúes < bayou, güines $<$ whin, jonrones $<$ home-runs. Obviously, lexical and semantic calques, being morphologically native, do comply with Spanish plurality rules: extensiones $<$ extension (cords), corredores $<$ runners, entradas $<$ innings (Rodríguez 2017). A few direct borrowings, keeping anglicized spelling and/or pronunciation, are not necessarily grammatically marked: los/las big leaguer, los carter, los left field, los dancing, los ómnibus, etc.

As regards gender assignment, the majority of the nouns annotated are inanimate, which explains why the majority of them are also considered patternless. Animate nouns, on the one hand, are grammatically marked, chiefly those related to occupations: lonchero(-a) 'diner server' < lunch, winchero( $-a)$ 'someone who works with a winch' $<$ winch, panquelero $(-a)$ 'pancake street vendor' $<$ pancake, pipero $(-a)$ 'tanker truck driver' $<$ pipe. The feminine gender is likewise found to denote tools or devices: lonchera 'lunch box', panquelera 'pancake maker', ponchadora < puncher; or places: ponchera $<$ punch 'place where tires are repaired', maltera $<$ malt 'cafeteria in which malt drink is sold'. Certain nouns remain unchanged in terms of gender: pantrista 'pantry worker', motorista 'street car driver'. The latter is also found in Sp. with the meaning of 'motorcycle rider'.

The patternless nature of inanimate nouns might stem from three possible sources: (1) adoption of the gender of a Spanish word with which the loans are associated, e.g. la barbacoa $\rightarrow$ la barbecue, el tabloncillo $\rightarrow$ el floor 'basketball court', el parque $\rightarrow$ el parque 'ballpark'; (2) arbitrary phonologically-induced assignment of gender, which might stem from the endings' graphemes, e.g. el fotingo $<$ foot in and go 'old car', el güito $<$ white 'skin whitish rashes', la paca < pack 'pack of paper'; (3) rules and regularities of Spanish, which are necessarily applied to newly-coined calques, e.g. la reservación $<$ reservation, la plomería < plumbing. Both endings in Spanish (-ción, -ería) call for feminine suffixation, which is therefore maintained and standardized.

Though obsolete compounds in nature, flower girl and ring boy denote gender through their rightmost units. An interesting remnant of these direct and cultural borrowings is damito, which is currently used to call the ring boy in a wedding. It is clearly a semantic distortion or oddity of the word dama 'maid', whose gender is anomalously shifted by using a masculine diminutive -ito. Cameraman, yet a noticeably English masculine noun, is currently used for both men and women, a sexist vestige of English word-building.

6 botar la pelota has a literal meaning of 'hitting out the ball' in a baseball game. 


\subsection{Derived and compound anglicisms}

In keeping with a general typology of linguistic borrowings, $\mathrm{Cu}$. compounds of English origin may stem from an array of processes. The commonest one is precisely the assimilation of originally English compounds without any visibly graphemic adaptation: baby-doll, background, bellboy, boxspring, coffeecake, handball, etc. Some forms might remain as compounds, but their bases are so adapted and fused that they are seemingly solid compounds: béisbol < baseball, dogao < dugout, carpor < car-port, siol < shortstop, tribey < three-base hit, etc. Compounding bases are also translated, but their composite form is kept: aeromoza < air-hostess, sírvase-usted < self-service, cargabates $<$ bat-carrier, besaculo < buttkisser. On some occasions, some English composites can be calqued and their target equivalent is a noun phrase: árbol del pan < breadfruit tree, baño de sol< sunbathe, cuello de tortuga < turtleneck, patrón de prueba < pattern test.

The adaptation of loanwords, both phonetically and graphemically, is also noticeable. A number of direct borrowings, especially nouns, undergo spelling shifting, which makes this assimilation procedure more deep-rooted: ampaya $<$ umpire, babiney $<$ bobbinet, sondy $<$ sundae, siol $<$ short-stop, tubey $<$ two-base hit. These last two examples (siol, tubey) portray how spelling and pronunciation are interrelated in terms of lexical borrowing, and how the adaptation process is dependent on the degree of difficulty of the newly-coined loan, or its frequency in the native language. At times, spelling changes in Spanish anglicisms lead to ungrammaticality in both languages: bride maid < bridesmaid, championismo < champion + -ism in English; or in Spanish: robador de base < base stealer. The word robador does not exist in Spanish, and it is restricted to a baseball game.

A distinction should be made between the derivation of established loans and the morphological assimilation that occurs during the borrowing process. Most of the units collected comply with the former, i.e. an autochthonous Spanish suffix is attached to an already-borrowed English base as in bisnero 'someone who is involved in illegal business' < business + -ero. Alternatively, some other cases are only morphological adaptation occurring within the target language, e.g. embolismo < embolism. However, this sort of distinction is not used in this research as a typological criterion.

In general, nouns are found to possess the widest range of suffixed units. The commonest noun-forming suffixes are attached to adapted bases: - ero $(a)$, -ista, -o, -ería, -ito(a). The first two are mostly related to occupations: bisnero 'smuggler' < business, pantrista < pantry, lonchero < lunch, pipero 'tanker truck' < pipe, quiropedista < chiropodist, plomero < plumber, etc. Suffix -ero(a), being graphemically analogous to English suffix -er, is also used to describe action-doers, places or objects: jonronero $<$ homerun, squiador < skier, fildeador < fielder, casetera < cassette player, pulguero < flea market. Suffix -ero(a) is also adjective-forming, and it is regularly found in relatively negative or humorous adjectives: palmolivero 'referring to someone who drinks alcohol on daily basis' $<$ Palmolive, beisbolero $<$ baseball, blofero 'characterized by showing off, or being too pretentious' $<$ bluff.

A productive noun-forming suffix, especially in abstract ones, is $-o$. The resulting nouns make reference to the general action stemming from a verbal base and a noun-forming suffix: bateo $<$ to bat, cacheo $<$ to catch, picheo $<$ to pitch, chequeo $<$ 
to check in, gardeo < to guard, facho 'to steal' < to fetch, escauteo 'the act of gathering information before a game to make the right decision' < to scout. At times, these words are believed to co-exist with less colloquial ones: cacheo/receptoría 'catching', picheo/lanzamiento 'pitching', gardeo/defensa 'defense', facho/robo 'stealing'.

Other relatively infrequent noun-forming suffixes have also been extracted in the glossary: -ería as in cremería, -ito as in shorcito, -ismo as in embolismo. The noun cremería < ice-cream parlor is a construct conveying the attachment of an adapted English base (crem-< cream) to a native place-forming suffix, complying with other analogous or equivalent forms in Spanish such as heladería, crepería, etc. Diminutive-forming suffix -ito, as commented earlier, is rather frequent, and it is mostly found in clothing-related units: shorcito $<$ shorts, pulovito $<$ pull-over, blumito 'women's underwear' < bloomers. Noun-forming suffix -ismo is restricted to a high sociolect, and it is rarely found: embolismo < embolism, championismo.

The existence of "pseudo-suffixes" in Cuban Spanish, though not common, is also tangible: gratindei 'free' < gratis + -dei, películey 'film' < película + -ey, ameriquein 'an American' < Americano + -ein. These suffixes are phonemically English-like, but their intention is merely to anglicize the native bases they are attached to. They are solely found in colloquial or slang language.

The coexistence of paronymic doublets, belonging to different borrowing types but conveying a similar lexical meaning is also noticed: high-ball/jaibolear; fraternity/fraternidad; jersey/yersi. Due to the graphemic and phonemic adaptation of loanwords, both forms remain in the language, and eventually the adapted form logically prevails: jaibolear, fraternidad, yersi (DEC 2003; GDA 2017). These duplets are highly productive in Cuban Spanish, especially in baseball jargon: home-run/ jonrón, dug-out/dogao, fielder/fildeador, etc.

Curiously, spelling variation may well lead to homonyms or homographs. That is to say, two different loanwords, whose origins and meanings differ, are grouped under the same entry or lemma due to coincidental graphemes and/or phonemes in the target language, i.e. Cuban Spanish. Therefore, fai is described as having two meanings: 'a break' < five, and 'a folder' < file. Another example is pie, in which two variants are outlined: 'a baked dessert having a filling' < pie, and 'a unit of measurement' < foot. The former variant is pronounced /pai/ whereas the latter one is /pie/, which explains their homography.

\section{References}

CDCE 2012 = Basterrechea Sosa I. 2012. Cubaneando: diccionario cubano-español. Miami. CORDE 2014 = Real Academia Española. 2014. Corpus diacrónico del español. [http:// corpus.rae.es/cordenet.html; last access: June 23, 2017].

CREA $2014=$ Real Academia Española. 2014. Corpus de referencia del español actual. [http://corpus.rae.es/creanet.html; last access: June 23, 2017].

DEC 2003 = Haensch G., Werner R. 2003. Diccionario del español de Cuba. Madrid.

DELCS 2017 = Sánchez Fajardo J.A. 2017. A dictionary of 1,000 English loan words in Cuban Spanish with usages, synonyms, and etymologies. New York. 
DLE 2014 = Real Academia Española. 2014. Diccionario de la lengua española. [http:// www.rae.es/diccionario-de-la-lengua-espanola/la-23a-edicion-2014; last access: June 23, 2017].

DMC 1999 = Sánchez-Boudy J. 1999. Diccionario mayor de cubanismos. Miami.

DPFC 1875 = Pichardo y Tapia E. 1875. Diccionario provincial casi razonado de vozes $y$ frases cubanas. [4 $4^{\text {th }}$ edition]. La Habana.

GDA $2017=$ Rodríguez González F. 2017. Gran diccionario de anglicismos. Madrid.

NCC $1974=$ Ortiz F. 1974. Nuevo Catauro de Cubanismos. La Habana.

Arnal Purroy M.L. 2009. ¿Para qué y para quién hacemos los diccionarios diferenciales? A propósito del Diccionario diferencial del español de Aragón. - Archivo de filología aragonesa 65: 113-137.

Ávila R. 2003-2004. ¿El fin de los diccionarios diferenciales? ¿El principio de los diccionarios integrales? - Revista de lexicografía 10: 7-20.

Cárdenas Molina G. 1999. Anglicismos en la norma léxica cubana. - Fuster M. et al. (eds.). Cuadernos de Filología 4: 15-57.

Cervantes-Rodríguez M. 2010. International migration in Cuba: Accumulation, imperial designs, and transnational social fields. The Pennsylvania State University Press.

Fasla Fernández D. 2007-2008. El español hablado de Cuba: préstamos vigentes, lexicogénesis, y variación lingüística. - Cuadernos de Investigación Filológica 33-34: 77-96.

Furiassi C., Pulcini V., Rodríguez F. 2012. The lexical influence of English on European languages. From words to phraseology. - Furiassi C. et al. (eds.). The anglicization of European lexis. Amsterdam: 1-26.

Gómez Capuz J. 1997. Towards a typological classification of linguistic borrowing (illustrated with anglicisms in Romance languages). - Revista Alicantina de Estudios Ingleses 10: 81-94.

González Mafud A.M. 2010. Muestras del habla culta de La Habana. La Habana.

Haensch G. 1991. La lexicografía del español de América en el umbral del siglo XXI. - Encuentro internacional sobre el español de América. Presencia y destino. El español de América hacia el siglo XXI. [Instituto Caro y Cuervo]. Santa Fé de Bogotá: 43-77.

Haugen E. 1950. The analysis of linguistic borrowing. - Language 26: 210-231.

Humbley J. 1974. Vers une typologie de l'emprunt linguistique. - Cahiers de Lexicologie 25: $46-70$.

López Morales H. 1970. El español de Cuba: situación bibliográfica. - Revista de Filología Española 51.1/4: 111-137.

López Morales H. 1971. Estudio sobre el español de Cuba. [Las Americas Publishing Company]. López Segrera F. 1989. Sociología de la colonia y neocolonia cubana. La Habana.

Lorenzo E. 1996. Anglicismos hispánicos. Madrid.

Lüdtke H. 1974. Historia del léxico románico. Madrid.

Marinello J. 1926-1927. Un guacalito de cubanismos. - Archivos del Folklore Cubano 2-4: 108-119, 228-235, 363-368. La Habana.

Montero Curiel P. 1995. Vocabulario de Madroñera (Cáceres). Cáceres.

Otheguy R., García O. 1988. Diffusion of lexical innovations in the Spanish of Cuban Americans. - Ornstein-Galicia J., Green G., Bixler-Márquez D. (eds.). Research issues and problems in United States Spanish 203-243. Brownsville (Tex.): 203-243.

Pérez L.A. 2008. On becoming Cuban: Identity, nationality and culture. [The University of North Carolina Press].

PEW Research Center. 2012. Hispanics of Cuban origin in the United States 2010. Washington D.C. [http://www.pewhispanic.org/2012/06/27/hispanics-of-cuban-origin-in-theunited-states-2010/; last access: September 08, 2016]. 
Rodríguez González F. 1995. Apuntes sobre lexicografía hispanoamericana. A propósito del Nuevo diccionario de americanismos tomo II: Nuevo diccionario de argentinismos, dirigido por Günther Haensch y Reihold Werner. - Revista de Lingüistica española 25: 169-180.

Rodríguez González F. 2002. Spanish. - Görlach M. (ed.). English in Europe. Oxford: 128-150. Rodríguez González F. 2017. El plural de los anglicismos en el español actual. Panorama y revisión crítica. - Boletín de la Real Academia Española 97: 299-329.

Sánchez Fajardo J.A. 2016. Anglicisms and calques in upper social class in pre-revolutionary Cuba: A sociolinguistic analysis. - IJES 16.1: 33-55.

Sánchez Fajardo J.A. 2017. Cuban-American Spanish revisited: Sociolinguistic and pragmatic peculiarities. - Zeitschrift für romanische Philologie 133: 789-825.

Santiesteban A. 1985. El habla popular cubana de hoy. La Habana.

Valdés Bernal S. 1998. Lengua Nacional e identidad cultural del cubano. La Habana. 